\title{
Consequences Customer Satisfaction : Service Quality and Perceived Value in the Moments Of Truth
}

\author{
Juliana ${ }^{1)}$, Theresia Jessica ${ }^{2)}$, Monica Widodo ${ }^{3)}$, Jessalyn Tanubrata ${ }^{4)}$ \\ Fakultas Pariwisata, Universitas Pelita Harapan, Indonesia \\ juliana.stpph@uph.edu (corresponding author)
}

\begin{abstract}
This study aims to explain the influence of service quality and perceived value on customer satisfaction at Starbucks US to understand first and second moments of truth. Consumers evaluate the quality when consumers buy an offer and when consuming it. This type of research is a quantitative study that uses the Hair theory, the sampling in this study uses a nonprobability sampling technique. The research population is 70 respondents who have been to Starbucks US as a sample of the author's study. The analysis tool uses SPSS ver 25 with a significance level of 0.05. Measurement variables, the measurement scale used in this study is the Likert scale. The results of this study can prove the hypothesis proposed by the author because it is proven that good service quality can influence customer satisfaction, and perceived value influences customer satisfaction because customers offered a good value compared to the price. So that the results of this study, it can be concluded that service quality and perceived value have a significant effect on customer satisfaction at Starbucks US.
\end{abstract}

Keywords: Service Quality, Perceived Value, Customer Satisfaction

\begin{abstract}
ABSTRAK
Penelitian ini bertujuan untuk menjelaskan pengaruh service quality dan perceived value terhadap customer satisfaction di Starbucks Amerika Serikat untuk memahami first and second moments of truth. Konsumen mengevaluasi kualitas saat konsumen membeli suatu penawaran dan saat mengkonsumsinya. Jenis penelitian ini adalah penelitian kuantitatif, pengambilan sampel dalam penelitian ini menggunakan teknik metode sampling jenuh. Adapun populasi dari penelitian ini sebesar 70 responden yang pernah berkunjung ke Starbucks Amerika Serikat sebagai sampel penelitian penulis. Alat analisis menggunakan SPSS ver 25 dengan tingkat signifikansi 0.05. Dalam pengukuran variabel, skala pengukuran yang digunakan dalam penelitian ini adalah skala likert. Hasil dari penelitian ini dapat membuktikan hipotesis yang diajukan oleh penulis karena terbukti service quality yang baik dapat memiliki pengaruh terhadap customer satisfaction, dan perceived value memiliki pengaruh terhadap customer satisfaction karena pelanggan merasa sesuai dengan apa yang dikeluarkan dengan yang di dapatkan. Sehingga melalui hasil dari penelitian ini, dapat disimpukan bahwa service quality dan perceived value memiliki pengaruh yang signifikan terhadap customer satisfaction Starbucks Amerika Serikat
\end{abstract}

Kata Kunci : Kualitas Pelayanan, Persepsi Nilai, Kepuasan Pelanggan

Naskah diterima: 23-05-2021, direvisi: 17-05-2021, diterbitkan: 01-09-2021

\section{PENDAHULUAN}

Menurut Lavinda (2020), Franchise (bahasa Inggris) atau "Francorum Rex" (bahasa latin) memiliki arti "Free From Servitude" atau "bebas dari ikatan". Franchise / Waralaba memiliki arti luas yaitu hak untuk menjual suatu jasa/produk dengan suatu sistem yang sudah ada dan sudah memiliki prosedur management yang baik dan tertata. Franchise diawali dari praktik bisnis di Eropa pada tahun 1840 dimana Raja di wilayah tertentu memberi wewenang kepada 
para bangsawan untuk menjadi tuan tanah dengan syarat harus memberikan keuntungan kepada Raja berupa imbalan pajak dan upeti. Dalam literatur berbeda, terlahirnya bisnis waralaba diketahui dari Amerika pada tahun 1860an yang dilakukan oleh Isaac Singer yaitu pencipta mesin jahit bermerk Singer lalu diikuti oleh banyak merek terkanal seperti Coca Cola, Mc Donalds, Hilton Hotel dan masih banyak lagi. Strategi bisnis ini bisa sangat terkenal dan berkembang sangat pesat dikarenakan sangat menguntungkan bagi penanam modal. Studi Löfgren et al. (2008) menyatakan bahwa konsumen membeli suatu produk dinilai sebagai first moment of truth, setelah pembelian dilakukan produk dikonsumsi dan dinilai sebagai second moment of truth. Ditemukan bahwa manfaat dan atribut dapat memiliki peran berbeda dalam memengaruhi kepuasan dan loyalitas pelanggan di berbagai siklus konsumsi. Hasil penelitian juga menunjukkan bahwa terdapat perbedaan yang signifikan kepuasan pelanggan terhadap loyalitas pelanggan pada awal moment of truth dengan moment of truth kedua.

Seiring perkembangan, konsep dari bisnis waralaba mulai di lirik oleh banyak pengusaha dan salah satu yang diminati adalah dengan adanya restoran waralaba berlisensi Starbucks yang mana popular di Amerika Serikat. Menurut Masdakaty (2015), hingga saat ini, Starbucks telah mempunyai lebih dari 25.085 toko di berbagai negara di dunia dengan pendapatan mereka mencapai miliaran. Dengan berkembangnya Starbucks dengan inovasi menciptakan berbagai minuman yang menjadi ciri khas, membawa Starbucks kepada hype yang luar biasa bahkan bisa dijadikan icon untuk setiap gerai kopi yang ada saat ini. Strategi marketing yang dilakukan pun terlihat dari icon logo starbucks mudah di ingat orang.

Starbucks terus berinovasi agar brand mereka tidak di tinggalkan oleh pelanggan dan juga dapat memberikan suatu dampak atau kesan yang tidak terlupakan oleh pelanggan dan oleh karena itu adanya metode untuk mengukur tingkat customer satisfaction yang sangat sering digunakan yaitu melihat Moment Of Truth dimana ada beberapa klasifikasi yang ada yaitu (Aryco, 2017): a) Zero Moment of Truth merupakan testimoni yang diberikan konsumen berupa review atas produk atau jasa dimana testimoni ini nantinya akan digunakan konsumen lainnya sebagai bahan pertimbangan dan pengambilan keputusan.

b) First Moment Of Truth merupakan situasi dimana konsumen memutuskan untuk melihat produk atau jasanya secara langsung.

c) Second Moment of Truth merupakan proses ketika konsumen menggunakkan produk atau jasa dan merasa satisfied atau tidak dengan jasa/produk yang diberikan.

Perceived value adalah kualitas dari produk yang diterima oleh pelanggan sesuai dengan apa yang di bayarkan (Yamin, 2013). Service Quality dapat diketahui dengan membandingkan ekspetasi dan pelayanan yang didapatkan.

Service quality bisa berupa uji survey atas customer satisfaction guna menjadi input bagi perusahaan agar dapat menjaga kualitas produk mereka karena dipersepsikan sangat baik dan sangat berkualitas. Sebaliknya jika pelayanan yang diterima lebih rendah, maka Service Quality dipersepsikan buruk. Jika mereka puas dengan pelayanan dan produk yang diberikan maka akan kembali kepada Zero Moment of Truth dimana pelanggan akan membagikan informasi atau testimoni tersebut kepada orang di sekitarnya melalui verbal dan non-verbal sehingga mendapatkan lebih banyak engagement dari customer secara tidak langsung.

Namun ada juga kondisi di mana terjadi penurunan customer satisfaction (Kotler, 2011) yang disebabkan oleh hal-hal berikut ini, yaitu:

1. Ketidaknyamanan tempat usaha dapat dikarenakan bising, berbau maupun kotor.

2. Ketidak ramahan karyawan atau karyawati yang melayani mereka.

3. Ketidaksesuaian ekspektasi yang didapatkan oleh customer.

4. Pelayan yang kurang cekatan dan memakan waktu yang lama.

5. Ketidakkonsistenan penjual dalam hal bahan baku.

6. Harga yang tidak bersahabat pun kadang menjadi kendala yang dapat dialami. 
Maka itu demi terciptanya customer satisfaction, diperlukan adanya keterampilan Pelayanan Prima dimana pelayanan yang diberikan ataupun produk yang ditawarkan harus mampu melampaui ekspektasi konsumen yang tidak akan didapatkan di manapun dan menjadi pengalaman yang tak terlupakan.

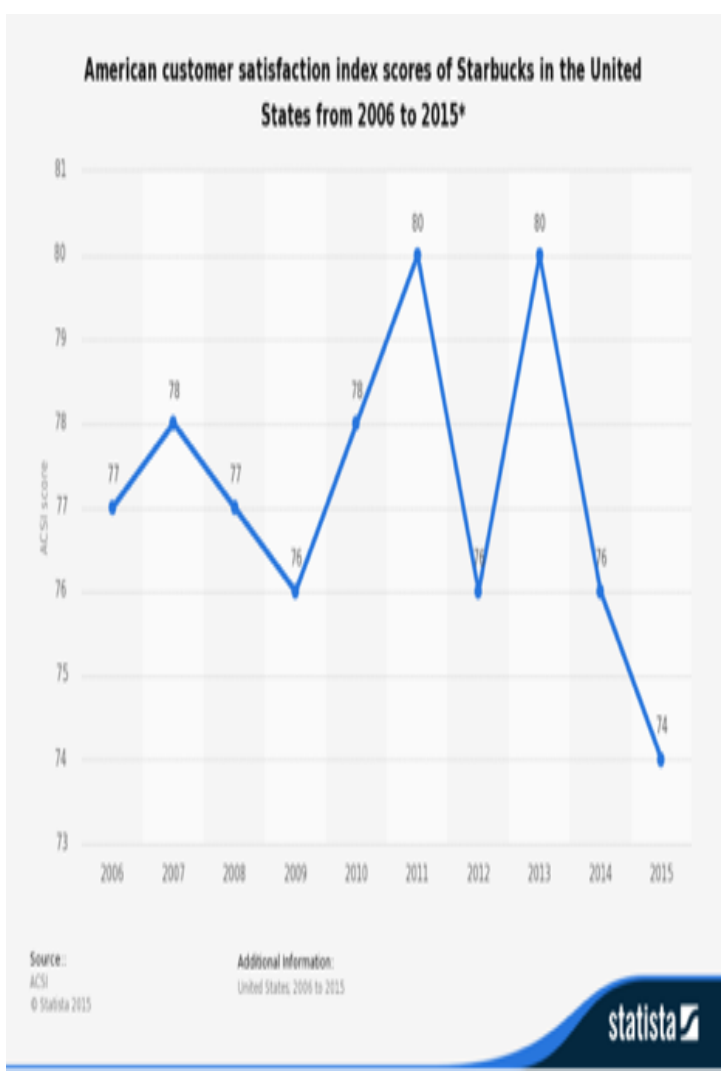

Sumber: (Lock, 2020)

Gambar 1. Grafik customer satisfaction
Dari grafik statistik diatas bisa dilihat adanya penurunan customer satisfaction dari tahun 2007 sampai 2009. Meskipun ada kenaikan dari tahun 2009-2011 dan 2012 ke 2013 tetapi kenaikan ini pun tidak significant karena masih ada penurunan di tahun $2011 \mathrm{ke}$ 2012 serta mengalami penurunan jauh lebih banyak dari yang diperkirakan pada tahun 2013-2015. Permasalahan adanya penurunan customer satisfaction bisa juga disebabkan oleh beberapa faktor yaitu pengaruh service quality yang tidak sesuai ekspektasi customer dan perceived value berdasarkan moment of truth. Rumusan masalah dalam penelitian ini apakah service quality dan perceive value dapat meningkatkan kepuasan pelanggan starbucks Amerika Serikat? Penelitian ini bertujuan untuk menjelaskan pengaruh service quality dan perceived value terhadap customer satisfaction di Starbucks Amerika Serikat.

\section{KAJIAN LITERATUR Kualitas Pelayanan}

Pelanggan merupakan target utama dalam hal loyalitas dan kepuasan, kepuasan pelanggan bisa terjadi karena adanya peningkatan kualitas jasa (Lupiyoadi \& Hamdani, 2006). Kesuksesan dari suatu perusahaan juga dapat dilihat dari kepuasan pelanggan karena konsistensi dari kualitas, jasa, atau produk berkontribusi di dalamnya. Parasuraman, Zeithaml, \& Berry (1985) mengembangkan Skala SERVQUAL yang digunakan sebagai metode untuk menilai service quality pada industri jasa. Dalam skala, mereka menggunakan lima dimensi umum berikut:
a) Tangibility
Semua yang memiliki wujud seperti peralatan, fasilitas, menu, fisik bangunan dan penampilan karyawan.
b) Reliability
Memberikan layanan dengan akurat dan handal
c) Responsiveness
Membantu pelanggan dalam segala hal dan pemberian pelayanan yang cepat
d) Assurance
Kemampuan dan sopan santun dari karyawan yang dapat meyakinkan dan mendapatkan rasa percaya dari pelanggan.
e) Empathy 
Perhatian tulus untuk setap individual pelanggan yang diberikan oleh karyawan kepada pelanggannya.

\section{Persepsi Nilai}

Menurut Kotler \& Keller (2012), produk yang memiliki nilai tinggi adalah produk yang diinginkan. dibutuhkan, dan memiliki permintaan oleh para pelangaan. Nilai yang di rasakan oleh pelanggan adalah hasil yang didapatkan dan dirasakan oleh pelanggan setelah membayar layanan dari suatu perusahaan dengan perusahaan sejenis yang serupa, perbedaan antara biaya yang telah dikeluarkan dan benefit yang didapatkan. Maka dari itu presepsi nilai adalah penilaian dari pelanggan secara keseluruhan mengenai apa yang telah diterima apakah sesuai dengan apa yang telah di keluarkan,

Menurut Hurriyati (2015), seorang pelanggan yang loyal dapat diidentifikasi karena mereka memiliki ciri - ciri yaitu tidak tertarik dengan produk serupa yang dimiliki oleh pesaing, merefrensikan poduk yang dimiliki oleh suatu perusahaan ke orang lain, melakukan pembelian suatu produk secara berulang - ulang, dan membeli produk produk lainnya yang dikeluarkan oleh suatu perusahaan.

\section{Kepuasan Pelanggan}

Kepuasan pelanggan secara umum dapat didefinisikan sebagai perasaan yang dirasakan oleh pelanggan bisa kecewa atau puas, setelah membandingkan ekspetasi dari suatu produk atau jasa terhadap realitanya, jika sesuai dengan ekspetasi dari pelanggan maka merasa puas jika tidak maka merasa kecewa. Berikut merupakan 4 metode yang dapat digunakan untuk mengukur kepuasan pelanggan menurut (Tjiptono \& Chandra, 2011):

1) Sistem saran dan keluhan

Dengan memberikan pelanggan kesempatan untuk memberikan kritik dan saran.

2) Ghost shopping

Menggunakan ghost shopper yang bereperan seabgai pelanggan.

3) Lost costumer analysis
Menganalisa yang harus ditingkatkan dengan menghubungi pelanggan yang telah tidak menggunakan jasa dari perusahaan,

4) Survei kepuasan pelanggan

Menggunakan metode survey dengan responden acak.

\section{Service Quality dan Kepuasan Pelanggan}

Studi Krishna Naik et al. (2010) menyatakan bahwa service quality merupakan hal yang sangat penting dalam meningkatkan kepuasan konsumen, mempertahankan konsumen, serta menciptakan loyalitas konsumen. Pelanggan tetap selalu diharapkan menjadi pelanggan setia dan merekomendasikan produk atau layanan kepada orang lain. Dengan demikian kualitas pelayanan yang baik akan mengakibatkan pelanggan yang puas dan terus menjadi pengguna produk, mempertahankan pangsa pasar yang ada. Dalam era persaingan seperti itu, akan muncul pelanggan yang setia, merekomendasikan produk kepada orang lain jika tingkat kepuasan pelanggan signifikan (Inamullah, 2012)

\section{Persepsi Nilai dan Kepuasan Pelanggan}

Studi Chen et al. (2017) membuktikan bahwa persepsi nilai konsumen yang terdiri dari nilai fungsional, nilai kondisional berpengaruh signifikan terhadap kepuasan pelanggan, tetapi nilai sosial, nilai emosional dan nilai epistemic tidak signifikan terhadap kepuasan pelanggan, sehingga perusahaan mobil Malaysia harus berusaha meningkatkan nilai fungsional, sosial, emosional dan epistemic dan nilai kondisional yang dapat meningkatkan kepuasan pelanggan (Jayakody, 2016)

\section{Penelitian sebelumnya yang relevan}

Berikut merupakan penelitian mengenai service quality, perceived value, dan customer satisfaction yang telah dilakukan sebelumnya, yaitu:

1. Menurut Han \& Lee (2016)

Kesimpulan dari penelitian yang dilakukan oleh Han \& Lee (2016) adalah service quality dan perceived value memiliki pengaruh terhadap customer satisfaction. 
Di karenakan berdampak ada kesadaran pelanggan tentang praktik restoran ramah lingkungan pada hubungan antara perceived value dan customer satisfaction. Terutama ketika pelanggan menyadari bahwa restoran mendorong mereka untuk berpartisipasi dalam praktik ramah lingkungan, hubungan antara perceived value yang dirasakan dan customer satisfaction menjadi lebih kuat.

2. Menurut Hong (2015)

Kesimpulan dari penelitian yang dilakukan oleh Hong (2015) adalah service quality memiliki pengaruh yang sangat signifikan terhadap perceived value dikarenakan semakin tinggi service quality maka akan membuat semakin tinggi persepsi nilainya. Dan perceived value pelanggan di Resto Buro Bar juga memiliki pengaruh signfikan terhadap customer satisfaction.

\section{Rerangka Teoritis}

Bedasarkan teori dan hasil penelitian teoritis yang telah dipaparkan terbentuk rerangka pemikiran yang menyangkut variabel - variabel yang menjadi pokok pembahasan penelitian ini, yaitu service quality, perceived value, dan customer satisfaction. Rerangka pemikiran dapat digambarkan sebagai:

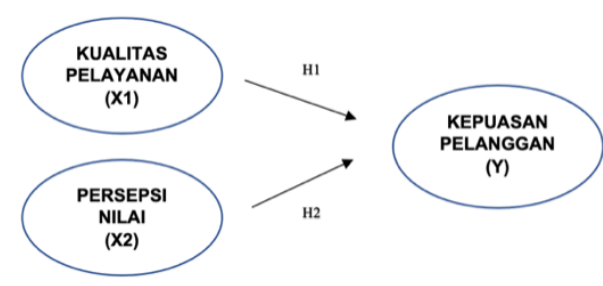

Gambar 2. Rerangka Pemikiran

\section{Hipotesis}

Menurut Dantes (2012), hipotesis adalah asumsi yang masih harus diuji kebenarannya melalui data dengan penelitian, sedangkan menurut Sekaran \& Bougie (2016), hipotesis adalah pernyataan tentative tetapi dapat diuji dengan tujuan memprediksi sesuatu yang diinginkan dalam data empiris.

Berdasarkan dua pernyataan diatas maka dapat disimpulkan bahwa hipotesis adalah pernyataan yang bersifat sementara sehingga diperlukan pengujian lanjutan yang menggunakan penelitian ilmiah untuk mencari tahu kebenaran dari suatu pendapat atau pernyataan tersebut.

\section{Hipotesis 1}

Menurut penelitian yang dilakukan oleh Hong (2015), menyatakan bahwa ketika kualitas pelayanan berpengaruh signifikan terhadap persepsi nilai. Dan persepsi nilai pelanggan berpengaruh signfikan terhadap kepuasan pelanggan yang menyebabkan peningkatan kepuasan pelanggan Resto Buro Bar Surabaya Apabila penilaian yang dihasilkan adalah penilaian positif, maka kualitas pelayanan memiliki pengaruh terhadap kepuasan pelanggan, sehingga hipotesis 1 sebagai berikut :

$\mathrm{H}_{\mathrm{o}}: \mu_{1}=\mu_{2}$ atau $\mathrm{H}_{\mathrm{o}}: \mu_{1}-\mu_{2}=0$

$\mu_{1}=$ Kualitas Pelayanan

$\mu_{2}=$ Kepuasan Pelanggan

$\mathrm{H}_{\mathrm{o}}=$ Kualitas pelayanan tidak memiliki pengaruh terhadap kepuasan pelanggan

$\mathrm{H}_{1}: \mu_{1} \neq \mu_{2}$ atau $\mathrm{H}_{\mathrm{o}}: \mu_{1}-\mu_{2} \neq 0$

$\mu_{1}=$ Kualitas Pelayanan

$\mu_{2}=$ Kepuasan Pelanggan

$\mathrm{H}_{1}=$ Kualitas pelayanan memiliki pengaruh terhadap kepuasan pelanggan

\section{Hipotesis 2}

Menurut penelitian yang dilakukan oleh Han \& Lee (2016), menyatakan bahwa Ketika pelanggan menyadari bahwa restoran mendorong mereka untuk berpartisipasi dalam praktik ramah lingkungan, hubungan antara persepsi nilai yang dirasakan dan kepuasan pelanggan menjadi lebih kuat. Apabila penilaian yang dihasilkan adalah penilaian positif, maka persepsi nilai memiliki pengaruh terhadap kepuasan pelanggan, sehingga hipotesis 2 sebagai berikut :

$\mathrm{H}_{\mathrm{o}}: \mu_{2}=\mu_{3}$ atau $\mathrm{H}_{\mathrm{o}}: \mu_{2}-\mu_{3}=0$

$\mu_{2}=$ Persepsi Nilai

$\mu_{3}=$ Kepuasan Pelanggan

$\mathrm{H}_{\mathrm{o}}=$ Persepsi nilai tidak memiliki pengaruh terhadap kepuasan pelanggan

$\mathrm{H}_{1}: \mu_{3} \neq \mu_{2}$ atau $\mathrm{H}_{\mathrm{o}}: \mu_{3}-\mu_{2} \neq 0$

$\mu_{2}=$ Persepsi Nilai

$\mu_{3}=$ Kepuasan Pelanggan

$\mathrm{H}_{2}=$ Persepsi nilai memiliki pengaruh terhadap kepuasan pelanggan

\section{METODE PENELITIAN}

Penelitian ini menggunakan metode kuesioner, jenis penelitian kuantitatif 
sedangkan dalam menganalisis data menggunakan statistik deskriptif. Pengambilan sampel dalam penelitian ini menggunakan teknik metode sampling jenuh. Adapun populasi dari penelitian ini sebesar 70 responden. Maka dari itu penulis mengambil 70 responden sebagai sampel penelitian penulis. Menurut Hair, Black, Babib, \& Anderson (2010), jumlah sampel minimal 5 kali dari jumlah indikator, jadi untuk menentukan jumlah sampel dapat menggunakan metode dimana jumlah variabel yang digunakan dikali dengan 5. Dalam pengukuran variabel, skala pengukuran yang digunakan dalam penelitian ini adalah skala likert.

\section{PEMBAHASAN}

Penulis telah menyebarkan total 70 kuesioner. Kuesioner tersebut disebarkan dengan menggunakkan link. Terdapat 2 bagian di dalam kuesioner yang telah disebarkan yaitu bagian I yang merupakan pertanyaan mengenai profil pribadi para responden dan bagian II yang merupakan pertanyaan mengenai service quality, perceived value, dan customer satisfaction.

Hasil analisis menunjukan data dengan total 70 responden, dapat dilihat bahwa mayoritas responden yang menjawab kuesioner adalah berjenis kelamin wanita yaitu sebanyak $58,6 \%$ (41 responden), sedangkan yang berjenis kelamin pria hanyalah $41,4 \%$ (29 responden). Dapat diketahui juga bahwa mayoritas umur responden yaitu 15-20 tahun yaitu sebesar $37,1 \%$ (26 responden), bahwa mayoritas responden adalah pelajar sebanyak 38 responden $(54,3 \%)$. Dapat diketahui juga, semua responden sudah pernah pergi ke Starbucks dan mayoritas responden pergi ke Starbucks 1 minggu sekali sebanyak 33 responden $(47,1 \%)$ serta pergi ke Starbucks yang berada di kota Los Angeles sebanyak 23 responden $(32,9 \%)$ dan sisanya di New York, San Fransisco, Honolulu, San Bernardino, dan kota lainnya, mayoritas responden memilih Caramel Macchiato sebagai menu favoritnya sebanyak 9 responden $(12,9 \%)$, Caramel Frappuccino sebanyak 8 responden $(11,4 \%)$, dan minuman lainnya.
Hasil analisis menunjukkan bahwa mayoritas responden setuju dengan indikator SQ 1 (Starbucks has menu that Is visually attractive) yaitu sebanyak 29 responden $(41,4 \%)$. Dapat dilihat bahwa mayoritas responden setuju dengan indikator SQ 2 (Sympathetic and reassuring employees) yaitu sebanyak 35 responden (50\%). Mayoritas responden setuju dengan indikator SQ 3 (Employees can answer questions completely) yaitu sebanyak 32 responden $(45,7 \%)$. Dapat dilihat bahwa mayoritas responden setuju dengan indikator SQ 4 (Maintaining speed and quality of service during busy times) yaitu sebanyak 25 responden $(35,7 \%)$. Dapat dilihat bahwa mayoritas responden setuju dengan indikator SQ 5 (Dependable and consistent) yaitu sebanyak 33 responden $(47,1 \%)$.

Hasil analisis menunjukkan bahwa mayoritas responden setuju dengan indikator PV 1 (I was offered a good value compared to the price I paid) yaitu sebanyak 29 responden $(41,4 \%)$. Dapat dilihat bahwa mayoritas responden setuju dengan indikator PV 2 (Starbucks has a high overall value) yaitu sebanyak 29 responden (41,4\%). Dapat dilihat juga pada Tabel 3 bahwa mayoritas responden setuju dengan indikator PV 3 (It is worthful than I spent) yaitu sebanyak 28 responden (40\%). Dapat dilihat bahwa mayoritas responden setuju dengan indikator PV 4 (I was offered a beveragelfood than I paid) yaitu sebanyak 24 responden $(34,3 \%)$.

Hasil analisis menunjukkan bahwa mayoritas responden setuju dengan indikator CS 1 (I think that I did the right thing when I purchased) yaitu sebanyak 31 responden $(44,3 \%)$. Dapat dilihat bahwa mayoritas responden setuju dengan indikator CS 2 (My overall experiences at Starbucks are satisfactory) yaitu sebanyak 32 responden (45,7\%). Dapat dilihat juga pada Tabel 4 bahwa mayoritas responden setuju dengan indikator CS 3 (Overall, I am satisfied with the Starbucks service) yaitu sebanyak 38 responden $(54,3 \%)$. Dapat dilihat bahwa mayoritas responden setuju dengan indikator CS 4 (This facility of Starbucks is exactly what is needed for this service) yaitu sebanyak 29 responden $(41,4 \%)$. 


\section{Uji Validitas}

Dapat dilihat pada uji validitas bahwa seluruh indikator memiliki Pearson Correlation yang lebih besar dari $r$ tabel sig. $0,235(5 \%)$, dimana seluruh indikator dinyatakan Valid.

\section{Uji Reliabilitas}

Tabel 1. Uji Reliabilitas

\begin{tabular}{llll}
\hline Variabel & $\begin{array}{l}\text { Chronbach's } \\
\text { Alpha Based } \\
\text { on } \\
\text { Standarized } \\
\text { Items }\end{array}$ & $\begin{array}{l}\text { Item } \\
\text { Item }\end{array}$ & \\
& & & \\
\hline Service & .845 & 5 & Reliabel \\
Quality & & & \\
\hline
\end{tabular}

\begin{tabular}{llll}
\hline $\begin{array}{l}\text { Perceived } \\
\text { Value }\end{array}$ & .740 & 4 & Reliabel \\
\hline $\begin{array}{l}\text { Customer } \\
\text { Satisfaction }\end{array}$ & .895 & 4 & Reliabel \\
\end{tabular}

. Sumber: Hasil Olahan Data (2020)

Dapat dilihat pada Tabel 1 bahwa chronbach alpha tiap variabel lebih besar dari 0.6 dan dinyatakan reliabel dan konsisten.

Koefisien Determinasi $\left(\mathrm{R}^{2}\right)$

Tabel 2. Model Summary Service Quality terhadap Customer Satisfaction

\begin{tabular}{|c|c|c|c|c|c|c|c|}
\hline $\begin{array}{l}\text { Mod } \\
\text { el }\end{array}$ & $\mathrm{R}$ & $\begin{array}{l}\mathrm{R} \\
\text { Squa } \\
\text { re }\end{array}$ & $\begin{array}{l}\text { Adjus } \\
\text { ted R } \\
\text { Suqar } \\
\text { e }\end{array}$ & $\begin{array}{l}\text { F } \\
\text { Chan } \\
\text { ge }\end{array}$ & $\begin{array}{l}\mathrm{df} \\
1\end{array}$ & $\begin{array}{l}\mathrm{df} \\
2\end{array}$ & $\begin{array}{l}\text { Sig } \\
\text { Chan } \\
\text { ge }\end{array}$ \\
\hline 1 & $\begin{array}{l}.73 \\
5^{\mathrm{b}}\end{array}$ & .541 & .505 & $\begin{array}{l}15.0 \\
73\end{array}$ & 5 & $\begin{array}{l}6 \\
4\end{array}$ & .000 \\
\hline
\end{tabular}

Sumber: Hasil Olahan Data (2020)

Tabulasi yang dilakukan dengan program SPSS, mendapatkan hasil koefisien determinasi $\left(\mathrm{R}^{2}\right)$ sebesar 0,505. Hal ini menunjukan bahwa indikator service quality terhadap Customer Satisfaction sebesar $50,5 \%$, sisanya dapat dijelaskan oleh variabel lainnya.

Signifikansi F sebesar 0,0000 membuktikan bahwa service quality berpengaruh terhadap Customer Satisfaction.

Tabel 3. ANOVA (Uji F)

\begin{tabular}{llllll}
\multicolumn{5}{c}{ Tabel 3. ANOVA (Uji F) } \\
\hline Mod & Sum & d & Mean & F & Sig \\
el & $\begin{array}{l}\text { of } \\
\text { Squar }\end{array}$ & f & Squa & & \\
& es & & & & \\
& & & & & \\
& & & & & \\
& &
\end{tabular}

\begin{tabular}{|lllllll}
\hline 1 & Regressi & 308.2 & 5 & 61.64 & 15.07 & .00 \\
on & 30 & & 6 & 3 & $0^{\mathrm{b}}$ \\
\hline Residual & 261.7 & 6 & 4.090 & & \\
& 52 & 4 & & & \\
\hline \multicolumn{5}{c}{} \\
& 569.9 & 6 \\
& 82 & 9 & & \\
\hline \multicolumn{5}{c}{ Sumber: Hasil Olahan Data (2020) }
\end{tabular}

Dapat dilihat pada Tabel 3 bahwa F hitung menunjukkan hasil 15,073 . Nilai dari $F$ tabel dengan df $1=5$ dan df $2=64$ adalah 2,360. Maka $\mathrm{F}_{\text {hitung }}>\mathrm{F}_{\text {tabel }}$ yang berarti menolak $\mathrm{H}_{\mathrm{o}}$ dan menerima $\mathrm{H}_{1}$, sehingga dapat disimpulkan service quality berpengaruh terhadap Customer Satisfaction

Tabel 4. Uji t

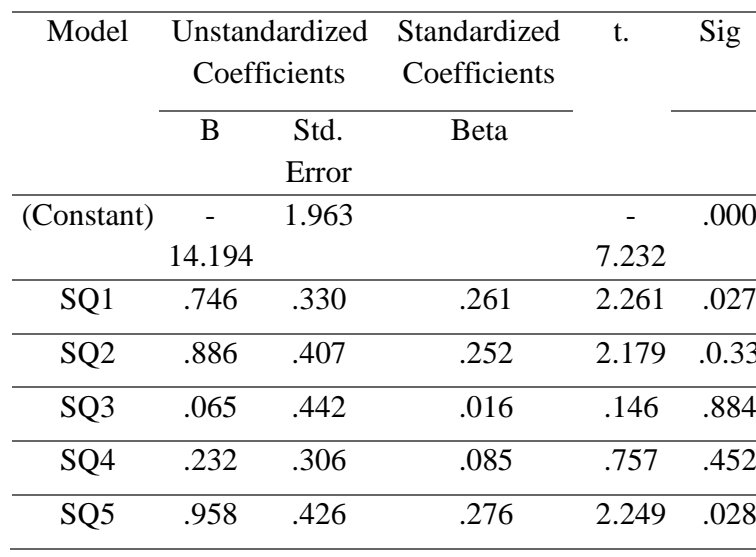

Sumber: Hasil Olahan Data (2020)

$\mathrm{Y}_{1}=\beta_{0}+\beta_{1} \mathrm{SQ} 1+\beta_{2} \mathrm{SQ} 2+\beta_{3} \mathrm{SQ} 3+\beta_{4} \mathrm{SQ} 4+$ $\beta_{5} \mathrm{SQ} 5+\mathrm{e}$

$\mathrm{Y}_{1}=-14,194+0,261 \mathrm{SQ} 1+0,252 \mathrm{SQ} 2+$ $0,016 \mathrm{SQ} 3+0,085 \mathrm{SQ} 4+0,276 \mathrm{SQ} 5+1,963$

Keterangan:

SQ1 = Starbucks has menu that Is visually attractive.

$\mathrm{SQ} 2=$ Sympathetic and reassuring employees.

$\mathrm{SQ3}=$ Employees can answer questions completely.

SQ4 = Maintaining speed and quality of service during busy times.

SQ5 = Dependable and consistent .

Berdasarkan Tabel 4, nilai $|\mathrm{t}|=7,232$. Sedangkan nilai $t_{\text {tabel }}$ dengan level of significant $\alpha=0,05$ dan $\mathrm{df}=\mathrm{n}-\mathrm{k}-1=66$ adalah sebesar 1,996. Karena nilai $|t|>t_{\text {tabel }}$ maka $\mathrm{H}_{\mathrm{o}}$ ditolak dan $\mathrm{H}_{1}$ diterima. Sehingga dapat disimpulkan bahwa service quality secara parsial berpengaruh terhadap Customer Satisfaction. 
Tabel 5. Model Summary Perceived Value terhadap Customer Satisfaction

\begin{tabular}{|c|c|c|c|c|c|c|c|}
\hline $\begin{array}{l}\text { Mod } \\
\text { el }\end{array}$ & $\mathrm{R}$ & $\begin{array}{l}\text { R } \\
\text { Squa } \\
\text { re }\end{array}$ & $\begin{array}{l}\text { Adjus } \\
\text { ted R } \\
\text { Suqar } \\
\text { e }\end{array}$ & $\begin{array}{l}\text { F } \\
\text { Chan } \\
\text { ge }\end{array}$ & $\begin{array}{l}\mathrm{df} \\
1\end{array}$ & $\begin{array}{l}\mathrm{df} \\
2\end{array}$ & $\begin{array}{l}\text { Sig } \\
\text { Chan } \\
\text { ge }\end{array}$ \\
\hline 1 & $9^{b}$ & .512 & .270 & $\begin{array}{l}7.37 \\
2\end{array}$ & 4 & 5 & .00 \\
\hline
\end{tabular}

Sumber: Hasil Olahan Data (2020)

Tabulasi yang dilakukan dengan program SPSS, mendapatkan hasil koefisien determinasi $\left(\mathrm{R}^{2}\right)$ sebesar 0,270. Hal ini menunjukan bahwa indikator Perceived Value terhadap Customer Satisfaction sebesar $27 \%$, sisanya dapat dijelaskan oleh variabel lainnya.

Signifikansi F sebesar 0,0000 membuktikan bahwa Perceived Value mempengaruhi Customer Satisfaction.

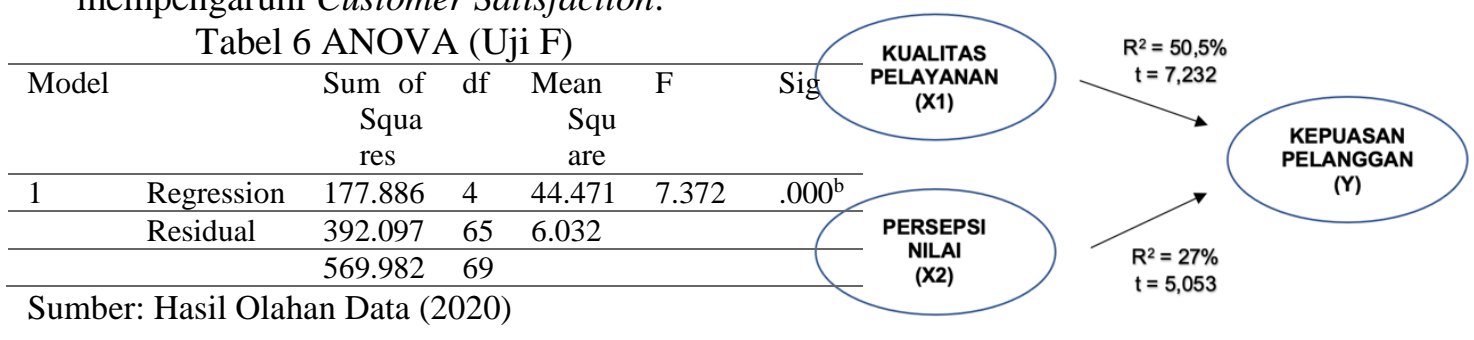

Dari Tabel 6 dapat dilihat bahwa $\mathrm{F}$ hitung menunjukan hasil 7,372. Nilai dari $\mathrm{F}$ tabel dengan df $1=4$ dan df $2=65$ adalah 2,510. Maka $F_{\text {hitung }}>F_{\text {tabel }}$ yang berarti menolak $\mathrm{H}_{\mathrm{o}}$ dan menerima $\mathrm{H}_{1}$, sehingga dapat disimpulkan Perceived Value berpengaruh terhadap Customer Satisfaction.

Tabel 7 Uji t

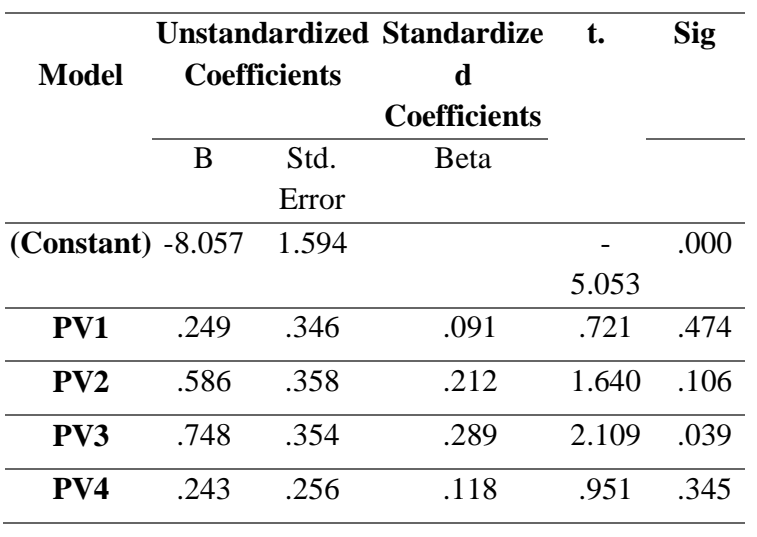

Sumber: Hasil Olahan Data (2020) $\mathrm{Y}_{1}=\beta_{0}+\beta_{1} \mathrm{PV} 1+\beta_{2} \mathrm{PV} 2+\beta_{3} \mathrm{PV} 3+\beta_{4} \mathrm{PV} 4+$ $\mathrm{e}$

ISSN: 2355-0295, e-ISSN: 2528-2255

http://ejournal.bsi.ac.id/ejurnal/index.php/ecodemica
$\mathrm{Y}_{1}=-8,057+0,091 \mathrm{PV} 1+0,212 \mathrm{PV} 2+$ $0,289 \mathrm{PV} 3+0,118 \mathrm{PV} 4+1,594$

Keterangan:

PV1 = I was offered a good value compared to the price I paid.

PV2 = Starbucks has a high overall value.

PV3 = It is worthful than I spent.

PV4 = I was offered a beverage/food than I paid.

Berdasarkan Tabel 7, nilai $|t|=5,053$. Sedangkan nilai $t_{\text {tabel }}$ dengan level of significant $\alpha=0,05$ dan $\mathrm{df}=\mathrm{n}-\mathrm{k}-1=66$ adalah sebesar 1,996. Karena nilai $|t|>t_{\text {tabel }}$ maka $\mathrm{H}_{\mathrm{o}}$ ditolak dan $\mathrm{H}_{1}$ diterima. Sehingga dapat disimpulkan bahwa Perceived Value secara parsial berpengaruh terhadap Customer Satisfaction.

Gambar 3. Hasil Akhir Penelitian

Dengan hasil $\mathrm{F}_{\text {hitung }}=15,073>\mathrm{F}_{\text {tabel }}=$ $2,360, \mathrm{t}_{\text {hitung }}=7,232>\mathrm{t}_{\text {tabel }}=1,996$ yang berarti $\mathrm{H}_{\mathrm{o}}$ ditolak dan $\mathrm{H}_{1}$ diterima. Hal ini menyimpulkan bahwa service quality berpengaruh terhadap customer satisfaction, indikator yang paling berpengaruh terhadap customer satisfaction adalah Employees can answer questions completely. Hasil ini sesuai dengan teori Han \& Lee (2016) yang menyebutkan bahwa service quality berpengaruh terhadap customer satisfaction. Model regresi hipotesis 1 adalah $50,5 \%$ yang menunjukan bahwa service quality dapat mempengaruhi customer satisfaction, dan sisanya dapat dijelaskan oleh variabel lainnya. Sedangkan untuk Hipotesis 2 dengan hasil $\mathrm{f}_{\text {hitung }}=7,372>\mathrm{f}_{\text {tabel }}=2,510, \mathrm{t}_{\text {hitung }}=5,053>$ $\mathrm{t}_{\text {tabel }}=1,996$ yang berarti $\mathrm{H}_{\mathrm{o}}$ ditolak dan $\mathrm{H}_{1}$ diterima. Hal ini menyimpulkan bahwa perceived value berpengaruh terhadap customer satisfaction, indikator yang paling berpengaruh terhadap customer satisfaction adalah Starbucks has a high overall value. 
Hasil ini sesuai dengan teori Hong (2015) yang menyebutkan bahwa perceived value memiliki pengaruh signifikan terhadap customer satisfaction. Model regresi hipotesis 2 adalah $27 \%$ yang menunjukkan bahwa perceived value dapat mempengaruhi customer satisfaction, dan sisanya dapat dijelaskan oleh variabel lainnya.

\section{SIMPULAN}

Hasil pengujian hipotesis penelitian menunjukkan bahwa service quality di Starbucks US berpengaruh signifikan terhadap customer satisfaction dengan indikator karyawan dapat menjawab pertanyaan dengan lengkap. Pengujian hipotesis perceived value juga menunjukan bahwa perceived value di Starbucks US dapat memengaruhi kepuasan pelanggan dengan indikator Starbucks memiliki nilai yang lebih tinggi dari harga yang dibayarkan dan Starbucks memiliki keseluruhan nilai yang tinggi. Tingkat kepuasaan konsumen di Starbucks US sebesar sudah dapat dibilang cukup dengan konsumen yang menyatakan puas dengan keseluruhan pelayanan Starbucks Amerika Serikat. Dapat disimpulkan bahwa service quality dan perceived value memiliki pengaruh terhadap customer satisfaction Starbucks Amerika Serikat Hasil penelitian penulis sejalan dengan hasil penelitian terdahulu yang dilakukan oleh Han \& Lee (2016) dan Hong (2015) yang menyatakan service quality dan perceived value dapat memengaruhi customer satisfaction. Berdasarkan simpulan di atas, peneliti memberikan beberapa rekomendasi saran untuk penelitian selanjutnya adalah melakukan penelitian lanjut dengan variabel yang lebih bervariasi, memperluas penelitian dengan menambah jumlah responden sehingga hasil dari penelitian dapat diterapkan, dan menambah waktu untuk penelitian sehingga mendapatkan hasil yang lebih rinci. Dengan menerapkan pendekatan sistem konsumsi dimungkinkan para manajer untuk merancanga suatu kemasan yang dapat menarik pelanggan pada first moment of truth dan pada saat yang sama menciptakan kepuasan pelanggan di second moment of truth.

\section{REFERENSI}

Aryco, H. (2017). Memenangkan Hati Customer Dengan Zero Moment of Truth.

Chen, L. L., Basit, A., \& Hassan, Z. (2017). The Impact of Customer Perceived Value on Customer Satisfaction: A Study on Malaysian Automobile Industry. International Journal of Accounting \& Business Management, 5(1), 93-110, http://doi.org/10.24924/ijabm/2017.04/v 5.iss1/93.110.

Dantes, N. (2012). Metode Penelitian. Andi.

Hair, Joseph F. William C. Black, Barry J. Babin, R. E. A. (2010). Multivariate Data Analysis (7th ed.). Pearson Prentice Hall.

Han, J. H., \& Lee, E. (2016). The effect of customer awareness of restaurants' green practices on customer dining experiences. International Journal of Tourism and Hospitality Research, 30(4), 57. https://doi.org/10.21298/ijthr.2016.04.30 .4 .57

Hong, B. (2015). Pengaruh Service Quality, Perceived Value, Customer Satisfaction Terhadap Repurchase Intention Pelanggan di Resto Buro Bar Surabaya. Jurnal Strategi Pemasaran, 3(1), 1-11.

Hurriyati, R. (2005). Bauran Pemasaran dan Loyalitas Konsumen. In Alfabeta Bandung.

Inamullah, K. (2012). Impact of customers Satisfaction And Customers Retention on Customers Loyalty. International Journal of Scientific \& Technology Research, 1(2), 106-110.

Jayakody D.H., S. G. . \& K. G. N. (2016). The Effect of Customer Perceived Value on Customer Satisfaction \& Loyalty: A case of Sri Lankan Pay-TV Industry - A Case of Sri Lanka Telecom PAY TV.

Kotler. (2011). Manajemen Pemasaran di Indonesia: Analisis, Perencanaan, Implementasi dan Pengendalian. In Jakarta : Penerbit Salemba Empat.

Kotler, Phillip, \& Keller, K. L. (2012). Marketing Management 13. Prentice Hall International, Inc. 
Krishna Naik, C. N., Gantasala, S. B., \& Prabhakar, G. V. (2010). Service Quality (Servqual) and its effect on customer satisfaction in retailing. European Journal of Social Sciences, 16(2), 239251.

Lavinda. (2020). Simak Definisi Bisnis Franchise dan Sejarah Kemunculannya.

Lock, S. (2020). American customer satisfaction index scores of Starbucks in the United States from 2006 to 2020.

Löfgren, M., Witell, L., \& Gustafsson, A. (2008). Customer satisfaction in the first and second moments of truth. Journal of Product and Brand Management, 17(7), 463-474.

https://doi.org/10.1108/10610420810916 362

Lupiyoadi, R., \& Hamdani. (2006). Manajemen Pemasaran Jasa. Salemba Empat.

Masdakaty, Y. (2015). Mengintip Sejarah Singkat Starbucks.

Parasuraman, A., Zeithaml, V. A., \& Berry, L. L. (1985). A conceptual model of service quality and its implications for future research. Journal of Marketing.

Sekaran, U., \& Bougie, R. (2016). Research Methods For Business: A Skill-Building Approach. Wiley.

Tjiptono, F., \& Chandra, G. (2011). Service, Quality \& Satisfaction (Edisi 3). Andi.

Yamin, R. (2013). Persepsi Nilai, Persepsi Kualitas, dan Citra terhadap Kepuasan Konsumen pada PT. Astra International Daihatsu di Manado. Jurnal EMBA: jurnal riset Ekonomi, Manajemen, Bisnis dan akuntansi, Volume 1 No. 3 (2013), 1231-1240,

DOI: https://doi.org/10.35794/emba.1.3. 2013.2530.

\section{BIODATA PENULIS}

Juliana dosen Program Studi Pengelolaan Perhotelan Fakultas Pariwisata Universitas Pelita Harapan

Theresia Jessica mahasiswa Fakultas Pariwisata Program Studi Pengelolaan Perhotelan Universitas Pelita Harapan
Monica Widodo mahasiswa Fakultas Pariwisata Program Studi Pengelolaan Perhotelan Universitas Pelita Harapan

Jessalyn Tanubrata mahasiswa Fakultas Pariwisata Program Studi Pengelolaan Perhotelan Universitas Pelita Harapa 